\title{
Children's Right to Freedom From Obesity: Responsibilities of the Food Industry
}

\author{
Ó Cathaoir, Katharina Eva
}

Published in:

Nordic Journal of Human Rights

Publication date:

2018

Document version

Peer reviewed version

Citation for published version (APA):

Ó Cathaoir, K. E. (2018). Children's Right to Freedom From Obesity: Responsibilities of the Food Industry. Nordic Journal of Human Rights, 36(2), 109-131.

https://www.tandfonline.com/doi/full/10.1080/18918131.2018.1505090 


\title{
Children's Right to freedom from obesity: Responsibilities of the Food Industry
}

\author{
Published in Nordic Journal of Human Rights Volume 36, 2018 - Issue 2 \\ Katharina Eva Ó Cathaoir \\ Postdoctoral researcher \\ Faculty of Law, University of Copenhagen
}

\begin{abstract}
Governments have failed to adequately tackle the rise in childhood obesity rates worldwide. Instead, food and beverage companies are increasingly relied upon to support public health efforts to prevent childhood obesity. Yet, the suitability of companies as public health partners must be questioned. This article asks whether international human rights law places responsibilities on food and beverage companies that could mitigate inherent conflicts. Companies' responsibilities in relation to children's rights to health and adequate food in the context of childhood obesity are analysed with reference to, inter alia, the United Nations Guiding Principles on Business and Human Rights, the Children's Rights and Business Principles and the Convention on the Rights of the Child. The human rights reports of a selection of major food and beverage companies are then evaluated in light of these sources. This article determines that, so far, the food and beverage companies reviewed have failed to acknowledge their impact on nutrition focused rights. Existing guidance leaves companies with too much flexibility to mitigate conflicts effectively. It is argued that stronger indicators on companies' responsibilities to respect children's right to freedom from obesity are necessary.
\end{abstract}

Keywords: Business and Human Rights; Children's Rights; Right to Adequate Food; Right to Health; Obesity; NCDs; Law

Acknowledgements: Sincere thanks to Professor Emeritus Wenche Barth Eide for comments on all earlier draft. Thank you also to the anonymous peer reviewers for their helpful feedback. This article is based on a chapter from my PhD thesis, 'A Children's Rights Perspective on Obesogenic Food Marketing' (Copenhagen, 2017). The work is supported by the research programme "Governing Obesity" funded by the University of Copenhagen Excellence Programme for Interdisciplinary Research (www.go.ku.dk).

\section{Introduction}

Global childhood obesity has reached epidemic proportions, harming children's health and spiking healthcare costs. To counter these trends, powerful global actors must address the drivers of childhood obesity, not least access to nutritious food. States have important regulatory powers, yet most have failed to adopt effective legal and policy measures. In response to this inertia, commentators argue that international human rights law (IHRL) places obligations on states to prevent and treat obesity. ${ }^{1}$ In light of the global impact of obesity, human rights could form an

\footnotetext{
${ }^{1}$ See, for instance, Amandine Garde, 'Advertising Regulation and the Protection of Children-Consumers in the European Union: In the Best Interests of ... Commercial Operators?' (2011) 19 Int'1 J Children's Rts 523; Elizabeth Handsley and others, 'A Children's Rights Perspective on Food Advertising to Children' (2014) 22 Int'l J Children's Rts 93; Katharina Ó Cathaoir, 'Childhood Obesity and the Right to Health' (2016) 18 Health and Hum Rights 249.
} 
important source of obligations; IHRL enshrines universal rights and corresponding responsibilities that apply in every state that ratifies the treaty.

Drawing on this growing discourse, this article analyses the human rights responsibilities of food and beverage companies contributing to the obesity epidemic, instead of focusing on states, the primary duty bearers under human rights. Obligations - what companies must do are legally binding, whereas our focus is on responsibilities - what companies should do. The article asks, to what extent do international human rights norms and practices provide a framework for holding the producers and promoters of unhealthy food products responsible for their adverse impact on children's rights? ${ }^{2}$ Specifically, what responsibilities do food and beverage companies have in relation to children's rights to health and adequate food in the context of obesity, and what actions do companies take to meet their responsibilities? Special focus is placed on the marketing of unhealthy food to children.

The article introduces childhood obesity as a global concern and the role of transnational food and beverage companies in contributing to its spread. Despite food companies' tactics, governments and international organisations frequently collaborate with them to prevent obesity. Although the World Health Organization (WHO) could play a powerful role in shaping norms at the global level, it has so far not been instrumental in clarifying food and beverage companies' responsibilities.

In light of this gap, I explore companies' responsibilities under IHRL with a focus on children's rights to adequate food and health under the Convention on the Rights of the Child $(\mathrm{CRC})^{3}$, the International Covenant on Economic, Social and Cultural Rights (ICESCR), ${ }^{4}$ and non-binding standards, including the United Nations Guiding Principles on Business and Human Rights (hereafter, UNGP), and the UNICEF Children's Rights and Business Principles (hereafter, Children's Principles). ${ }^{5}$ Guidance from the United Nations Special Rapporteur on the right of everyone to the enjoyment of the highest attainable standard of physical and mental health (hereafter, Special Rapporteur on the right to health), and the Special Rapporteur on the right to food, is also analysed.

The article then evaluates the extent to which a selection of major food and beverage companies internalise the guidance coming from the above bodies and analyse their adverse impacts on nutrition rights in the context of obesity. The 2016 human rights policies emanating from Coca-Cola, Mars, PepsiCo, Nestlé, McDonald's, General Mills and Mondelez are assessed as these entities represent a mixture of food and beverage companies, and restaurants. Given their market position, these multinationals are likely to have both a significant impact on the above-mentioned rights, and the resources to assess and remedy this impact. Finally,

\footnotetext{
${ }^{2}$ While there is no universal definition of 'unhealthy', this piece relies on the nutrient profile developed by the WHO's European regional office for the regulation of unhealthy food marketing. WHO Regional Office for Europe, WHO Regional Office for Europe Nutrient Profile Model (WHO 2015).

${ }^{3}$ Convention on the Rights of the Child (CRC) (adopted 20 November 1989, entered into force 2 September 1990) 1577 UNTS 3.

${ }^{4}$ International Covenant on Economic, Social and Cultural Rights (ICESCR) (adopted 16 December 1966, entered into force 3 January 1976) 993 UNTS 3.

${ }^{5}$ John Ruggie, 'Report of the Special Representative of the Secretary General on the issue of human rights and transnational corporations and other business enterprises, John Ruggie, Guiding Principles on Business and Human Rights: Implementing the United Nations 'Protect, Respect and Remedy' Framework' (21 March 2011) A/HRC/17/31; UNICEF, Save the Children and UN Global Compact, 'Children's Rights and Business Principles' (2012).
} 
recommendations are made on how to better entrench food and beverage companies' responsibilities for consumer health, with the potential of The Binding Treaty on Business and Human Rights considered.

\section{The Global Challenge of Childhood Obesity}

Childhood obesity is a global concern due to its increased prevalence worldwide, its impact on children's health, and the associated health care costs. ${ }^{6}$ WHO estimates that there are approximately 42 million children with obesity. ${ }^{7}$ While rates in the developed world are stabilising, there has not been significant reductions in prevalence. Instead, obesity is rising fastest in middle-income countries. ${ }^{8}$ Childhood obesity is a contributor to and risk factor of noncommunicable diseases (NCDs) in childhood and adolescence, including diabetes, cardiovascular problems and certain cancers. ${ }^{9}$ Further, children with obesity experience stigmatisation, bullying and social isolation. ${ }^{10}$ Additionally, having obesity in childhood substantially increases the likelihood of having obesity as an adult. ${ }^{11}$

Obesity also leads to direct and indirect costs, highlighting the business case for childhood obesity prevention. In the US, a recent study estimated the average lifetime medical cost of a child with obesity was 19,000 USD. ${ }^{12}$ In 2007, WHO Europe assessed that obesity was responsible for up to $6 \%$ of healthcare costs in the region (due to increased prevalence, this percent has likely increased). ${ }^{13}$ The World Food Programme estimates that, in 2014, over nutrition cost Chile, Ecuador and Mexico 493 million USD, 13.1 billion USD and 7.3 billion USD respectively in healthcare and absenteeism. ${ }^{14}$ As obesity rates increase, the related costs will rise.

${ }^{6}$ For example, European Commission, 'European Union action plan on childhood obesity 2014 - 2020' (24 February 2014); WHO, 'Why does Childhood Obesity and Overweight Matter?' <http://www.who.int/dietphysicalactivity/childhood_consequences/en/> accessed 14 May 2017.

${ }^{7}$ Marie $\mathrm{Ng}$ and others, 'Global, regional, and national prevalence of overweight and obesity in children and adults during 1980-2013;2013: a systematic analysis for the Global Burden of Disease Study 2013' (2014) 384 Lancet 766.

${ }^{8}$ Mercedes de Onis, Monika Blössner and Elaine Borghi, 'Global prevalence and trends of overweight and obesity among preschool children' (2010) 92 The American Journal of Clinical Nutrition 1257.

${ }^{9}$ A. Llewellyn and others, 'Childhood obesity as a predictor of morbidity in adulthood: a systematic review and meta-analysis' (2016) 17 Obesity Reviews 56.

${ }^{10}$ Rebecca W Rees and others, 'It's on your conscience all the time': a systematic review of qualitative studies examining views on obesity among young people aged 12-18 years in the UK' (2014) 4 BMJ Open 1.

${ }^{11} \mathrm{WHO}$, Report of the commission on ending childhood obesity (2016); M. Simmonds and others, 'Predicting adult obesity from childhood obesity: a systematic review and meta-analysis' (2016) 17 Obes Rev 95.

${ }^{12}$ Eric Andrew Finkelstein, Wan Chen Kang Graham and Rahul Malhotra, 'Lifetime Direct Medical Costs of Childhood Obesity' (2014) 133 Pediatrics 1.

${ }^{13}$ Francesco Branca, Haik Nikogasian and Tim Lobstein (eds), The Challenge of Obesity in the WHO European Region and the strategies for response: summary (WHO Europe 2007) $<$ http://www.euro.who.int/en/publications/abstracts/challenge-of-obesity-in-the-who-european-region-and-thestrategies-for-response-the.-summary> accessed 14 May 2017.

${ }^{14}$ Andrés Fernandez and Rodrigo Martínez, The double burden: The combined economic impact of undernutrition and obesity in Latin America and the Caribbean (World Food Programme 2017) 52. 


\subsection{The role of the food and beverage industry}

Over the last decades, there has been a dramatic shift in what individuals eat, a shift that is spreading. While there is no universal definition of unhealthy food, there is general agreement on its characteristics: nutrient poor and high in fat, salt and sugar. High intake of refined carbohydrates, added sugars, fats, and animal-source foods now define the Western diet. ${ }^{15}$ Sugar, once a luxury commodity, is consumed in higher quantities than ever before, especially through sugar sweetened beverages ${ }^{16}$ Sales of ultra-processed foods have soared in high-income countries with middle-income economies mirroring these patterns. ${ }^{17}$ In Canada, the increase of total calories from ultra-processed food rose from $24.4 \%$ in 1938 to $54.9 \%$ in 2001; In Brazil, from $18.7 \%$ in 1987 to $26.1 \%$ in $2003 .{ }^{18}$

With unhealthy diet being a major contributor to obesity, the role of the companies that promote and produce this food should be analysed. ${ }^{19}$ As a small group of multinationals dominate the global food economy, changes in their practices could positively contribute to healthy diets. Worldwide, the top ten packaged food companies make up $15.2 \%$ of sales. The top ten soft drink companies account for $52.3 \%$ of sales worldwide, with Coca-Cola and PepsiCo comprising $25.9 \%$ and $11.5 \%$ of sales, respectively. ${ }^{20}$ These companies profit from selling ultraprocessed food (nutrient dense, high in salt and sugar, with little to no vitamins), which is longlasting, and therefore offers larger profit margins than fresh foods. ${ }^{21}$ Given the size of their market share and the epidemic of obesity, we should consider whether food companies have responsibilities beyond profits.

The need to examine food and beverage companies is heightened as they increasingly target middle and low-income countries that offer underexplored markets with huge, fast growing populations. Simultaneously, childhood obesity rates are rising fastest in middle-income states. $^{22}$ Obesity is also increasing in low-income countries, leading to a 'double burden' of both under and over nutrition. ${ }^{23}$ Globalisation, trade liberalisation, ${ }^{24}$ urbanisation, and

${ }^{15}$ Rob Moodie and others, 'Profits and pandemics: prevention of harmful effects of tobacco, alcohol, and ultraprocessed food and drink industries' (2013) 381 Lancet 670.

${ }^{16}$ Barry M. Popkin, Linda S. Adair and Shu Wen Ng, 'NOW AND THEN: The Global Nutrition Transition: The Pandemic of Obesity in Developing Countries' (2012) 70 Nutr Rev 3.

${ }^{17} \mathrm{P}$. Baker and S. Friel, 'Food systems transformations, ultra-processed food markets and the nutrition transition in Asia' (2016) 12 Global Health 80.

${ }^{18}$ CA Monteiro and others, 'Ultra-processed products are becoming dominant in the global food system' (2013) 14 Obes Rev 21.

${ }^{19}$ Although the causes of obesity are multifaceted, including behavioural and genetic factors, obesity is primarily associated with unhealthy diet and lack of physical exercise. See, for instance: WHO, Global Status Report on NCDs 2014 (WHO 2014). For a critical account of this explanation: SW.Keith and others, 'Putative contributors to the secular increase in obesity: exploring the roads less traveled' (2006) 30 Int J Obes 1585.

${ }^{20}$ Eleanore Alexander, Derek Yach and George A. Mensah, 'Major multinational food and beverage companies and informal sector contributions to global food consumption: implications for nutrition policy' (2011) 7 Global Health 26.

${ }^{21}$ Moodie and others (n 15).

${ }^{22}$ Popkin and others (n 16).

23 Trishnee Bhurosy and Rajesh Jeewon, 'Overweight and Obesity Epidemic in Developing Countries: A Problem with Diet, Physical Activity, or Socioeconomic Status?' (2014) Sci World J 1; Asnawi Abdullah, 'The Double Burden of Undernutrition and Overnutrition in Developing Countries: an Update' (2015) 4(3) Curr Obes Rep 337. 
Westernisation ${ }^{25}$ enable this 'nutrition transition' - a dietary shift from traditional diets high in grains or other carbohydrates to a Western one high in sugar, fat and animal protein. Indeed, purchases of snack foods are increasing fastest in low income countries. ${ }^{26}$ Over the last decades, the cost of processed food has also decreased, while fruit and vegetable prices has continued to soar. $^{27}$

Marketing of unhealthy food is one dimension of this 'obesogenic' environment. ${ }^{28} \mathrm{~A}$ series of systematic literature reviews concludes that food marketing targeting children is widespread, with unhealthy foods, such as breakfast cereals, soft drinks, and fast foods, most heavily advertised. Food promotion can: impact children's nutritional knowledge and perception of a healthy diet through influencing their food preferences, purchasing choice and requests; This, in turn, affects their consumption behaviours and diet-related health status, making food promotion a significant independent determinant of food behaviours and health status. ${ }^{29}$ There is modest evidence that television advertising influences children's food and beverage preferences, and strong evidence that advertising impacts children's purchase choice and requests. ${ }^{30}$

In recent years, digital marketing has exploded, fuelled by an increase in the number and sophistication of interactive games, the rise of social media, data collection, profiling, and smartphones, as well as mobile marketing. ${ }^{31}$ This form of marketing may be even more successful at tapping into emotional or sub-conscious choices, ${ }^{32}$ allowing for more engagement than traditional media. ${ }^{33}$ Digital marketing can be cheaper for companies than broadcast, allowing food companies to target untapped developing markets through aggressive marketing campaigns. ${ }^{34}$ Further, regulating digital marketing is more complex due to the borderless nature of the Internet, ${ }^{35}$ with regulatory systems designed for broadcast media failing to encompass online media. ${ }^{36}$

${ }^{24}$ Ivana Kolčić, 'Double burden of malnutrition: A silent driver of double burden of disease in low- and middle-income countries' (2012) 2 JGH 1.

25 Jervase Ekezie and others, 'Impact of urbanization on obesity, anthropometric profile and blood pressure in the Igbos of Nigeria' (2011) 3 NAJMS 242.

${ }^{26}$ David Stuckler and others, 'Manufacturing Epidemics: The Role of Global Producers in Increased Consumption of Unhealthy Commodities Including Processed Foods, Alcohol, and Tobacco' (2012) 9 PLOS Medicine 1.

${ }^{27}$ John Cawley, 'The economics of childhood obesity' (2010) 29 Health Aff 364.

28 Tim Lobstein and others, 'Child and adolescent obesity: part of a bigger picture' (2015) 385 Lancet 2510.

${ }^{29}$ Gerard Hastings and others, 'Review of research on the effects of food promotion to children' (University of Strathclyde 2003); AE Matthews, 'Children and obesity: a pan-European project examining the role of food marketing' (2008) 18 Eur J Public Health 7.

${ }^{30} \mathrm{G}$ Cairns and others, 'Systematic reviews of the evidence on the nature, extent and effects of food marketing to children. A retrospective summary' (2013) 62 Appetite 209.

${ }^{31}$ Kathryn Montgomery and others, 'The New Threat of Digital Marketing (2012) 59(3) Pediatr Clin North Am 661.

${ }^{32}$ Kathryn Montgomery and others, Food Marketing in the Digital Age: A Conceptual Framework and Agenda for Research (Center for Digital Democracy 2011).

${ }^{33}$ R Bailey, K Wise, and P Bolls, 'How Avatar Customizability Affects Children's Arousal and Subjective Presence During Junk Food-Sponsored Online Video Games' (2009) 12(3) Cyberpsychol Behav.

${ }^{34}$ Consumers International, 'The Junk Food Trap: marketing unhealthy food in Asia and the Pacific Region' (Consumers International 2008).

35 WHO Europe, Tackling food marketing to children in a digital world: trans-disciplinary perspectives (WHO Europe 2016) 20.

${ }^{36}$ Hans J Kleinsteuber, 'The Internet between Regulation and Governance' in Christian Möller and Arnaud Amouroux (eds) The Media Freedom Internet Cookbook (OSCE 2004) 62-3. 
Accordingly, international bodies recommend that states limit marketing to prevent childhood obesity. ${ }^{37} \mathrm{WHO}$ has issued non-binding guidelines on best practice: the set of recommendations on marketing of foods and non-alcoholic beverages to children. ${ }^{38}$ Still, reviews highlight that no state has effectively and fully implemented the WHO recommendations. ${ }^{39}$ Instead of regulating, as explored below, governments often allow the food industry to selfregulate with little oversight.

\subsection{WHO guidance on companies' responsibilities}

Given the global reach of multinational food companies, WHO - with its constitutional mandate to direct and coordinate global health - can assist in defining the responsibilities of food companies. ${ }^{40}$ Under its Constitution, WHO can negotiate binding treaties with respect to any matter within the competence of the Organization, can issue binding regulations concerning specific concerns and make non-binding recommendations on any matter within its competence. ${ }^{41}$ In light of its Constitution, WHO has the competence to enact conventions and agree on recommendations related to promoting a healthy diet. ${ }^{42}$ WHO's mandate includes stimulating and advancing work to eradicate epidemic, endemic and other diseases; promoting the improvement of nutrition; and developing, establishing and promoting international standards with respect to food. However, as we will see, obesity is highly political and contentious, making agreement among states on the need for binding law unlikely.

WHO has not negotiated binding rules on obesity, but has issued relevant policy documents with recommendations to states and other stakeholders, including businesses. ${ }^{43}$ In its technical documents and policies, WHO consistently encourages states to work with the food industry through private sector engagement and partnerships ${ }^{44}$ 'where appropriate'. ${ }^{45}$ At the same time, co-operation with the private sector should ensure 'avoidance of potential conflicts of interest'. ${ }^{46}$ Yet, WHO's approach to food companies is too open-ended to promote effective change. The Global Strategy on Diet and Physical Activity (hereafter, the Strategy) - arguably the most important WHO policy document in the context of obesity - recommends that the food industry: promotes healthy diets and physical activity in line with national and international standards; limits fats, sugars and salts in products; develops affordable, healthy and nutritious

${ }^{37}$ UN General Assembly, 'Political Declaration of the High-Level Meeting of the General Assembly on the Prevention and Control of Non-Communicable Diseases' (2011) A/66/2, 43(f)(g).

${ }^{38}$ WHO, Set of Recommendations on the Marketing of Foods and Non-Alcoholic Beverages to Children (WHO 2010); WHO, A Framework for Implementing the Set of Recommendations on the Marketing of Foods and NonAlcoholic Beverages to Children (WHO 2012).

${ }^{39}$ Stefanie Vandevijvere and others, 'Progress achieved in restricting the marketing of high-fat, sugary and salty food and beverage products to children' (2016) 94 Bull World Health Organ 540.

${ }^{40}$ Constitution of the World Health Organization (adopted 22 July 1946, entry into force 4 July 1948) 14 UNTS 185 art 2(a).

${ }^{41}$ Ibid arts 19-23.

${ }^{42}$ Ibid, arts 19, 23. See also, Consumers International and others, 'Open Letter to Margaret Chan And José Graziano Da Silva Ahead of The Second International Conference On Nutrition’ (ICN2) (17 November 2014).

${ }^{43}$ For instance: WHO, Global Strategy on Diet Physical Activity and Health (WHO 2004); WHO, Global Action Plan for the Prevention and Control of Noncommunicable Diseases 2013-2020 (WHO 2013).

${ }^{44}$ ECHO (n 11) 36.

${ }^{45}$ Global Action Plan (n 43) 22.

46 WHA 'Global strategy on diet, physical activity and health' (22 May 2004) WHA57.17 5(6). 
choices; provides adequate information to consumers and authorities, including labels and evidence based health claims; and practices responsible marketing. ${ }^{47}$

These broad standards can conflate the roles of the state and companies, ignoring the inherent conflicts between the aims of food industry profit making by selling as much food as possible, as well as the aims of the Strategy to promote a healthy diet and discouraging excessive consumption. ${ }^{48}$ Further, the recommendations in the Strategy do not clarify states' role in navigating the conflicts. States are mainly encouraged to support the informed consumer, not to regulate the private actors that supply the food contributing to this epidemic. Important concepts like 'healthy', 'adequate', and 'appropriate' are undefined. In later documents, WHO has been more explicit, calling for reductions in salt, saturated fats, free and added sugars, elimination of transfats and limits to portion sizes. ${ }^{49}$ Further, WHO has produced regional nutrient profiles to guide regulators in determining what food should not be marketed to children. ${ }^{50}$

Yet, WHO's anticipated Framework of Engagement with Non-State Actors (FENSA) focuses on risk assessment and management within WHO, not governing corporate practices. ${ }^{51}$ The WHO Department of Nutrition for Health and Development's 2016 recommendations are of more guidance, highlighting transparency, participation, and accountability, including: civil society engagement, exclusion criteria for partnerships, legislation and governance in the development of nutrient profiles, pooling industry funding to finance research and policies, publishing communications between the industry and government, and monitoring industry progress. ${ }^{52}$ While useful, the advice is not binding nor has the World Health Assembly (WHA) endorsed it, limiting the recommendations' import for now. WHA should discuss and ideally endorse these recommendations. By avoiding tackling these conflicts head on, WHO is failing to ensure the highest attainable standard of global health. WHO must do more to guide companies on acting in line with the aims of WHO - 'the attainment by all peoples of the highest possible level of health'.

${ }^{47}$ Strategy 13-14; Global Action Plan 98.

${ }^{48}$ See, for example, K Brownell and K Warner 'The Perils of Ignoring History: Big Tobacco Played Dirty and Millions Died. How Similar Is Big Food?’ (2009) 87(1) Milbank Q 259; Jonathan Gornall, Sugar: spinning a web of influence (2015) BMJ 350. Since the submission of this article, these conflicts have been addressed in detail in Amandine Garde, Bill Jeffery and Neville Rigby, 'Implementing the WHO Recommendations whilst avoiding real, perceived or potential conflicts of interest' EJRR (2017) 8(2) 237.

${ }^{49}$ Global Action Plan (n 43) 33. For a detailed analysis of WHO's instruments in the field of obesity, see, K Ó Cathaoir, M Hartlev, C Brassart-Olsen, 'Global Health Law and Obesity: towards a complementary approach of public health and human rights law' in GL Burci and B Toebes (eds), Research Handbook on Global Health Law (Routledge, 2018).

${ }^{50}$ WHO Nutrient Profile Model for the Western Pacific Region: A tool to protect children from food marketing (2016); WHO Nutrient Profile Model for South-East Asia Region. To implement the set of recommendations on the marketing of foods and non-alcoholic beverages to children (2017).

${ }^{51}$ WHA, 'Framework of engagement with non-State actors' (28 May 2016) WHA69.10; Kent Buse, Sarah Hawkes, 'Sitting on the FENSA: WHO engagement with industry' (2016) 388(10043) Lancet 446; WHO Global Coordination Mechanism on the Prevention and Control of Noncommunicable Diseases, 'Final report and recommendations from the Working Group on ways and means of encouraging Member States and non-State actors to realize the commitment included in paragraph 44 of the Political Declaration of the High-level Meeting of the United Nations General Assembly on the Prevention and Control of Noncommunicable Diseases' (WHO May 2016).

$52 \mathrm{WHO}$, 'Addressing and Managing Conflicts of Interest in the planning and delivery of nutrition programmes at country level' (WHO Geneva 2016) 28. 
Food companies can benefit from playing a role in preventing obesity, as encouraged by the Strategy. Demand for 'healthy' food is growing, meaning there is an increasing incentive for 'big food' to take nutrition seriously to maintain its consumer base. The organic food market in the EU doubled from 2004 - 2015 to 24 billion euro. ${ }^{53}$ 'Better for you' snacks constitute a growing market in the US, bringing in $\$ 19.3$ billion of sales in $2015 .{ }^{54}$ Further, reputation is a strong incentive. The food industry risks becoming 'the new tobacco', which will likely affect profits and encourage public support for government regulation. Governments agree, under article 5.3 of the WHO Framework Convention on Tobacco Control, to protect their public health policies 'from commercial and other vested interests of the tobacco industry in accordance with national law' ${ }^{55}$ However, tobacco is a single harmful product, while food encompasses healthy and unhealthy products. Ultimately, by claiming to be a partner in obesity prevention, the food industry can argue that regulation is unnecessary and shape policies in a manner favourable to their interests.

Indeed, far from acting as the partner envisaged in the Strategy, food and beverage companies often oppose and obstruct government regulation. ${ }^{56}$ For instance, the sugar industry lobbied against the WHO's technical report on Diet, Nutrition and the Prevention of Chronic Disease, resulting in a watering down of (non-binding) recommendations. ${ }^{57}$ Soda companies, in particular, are gaining a negative reputation for using tactics akin to those of tobacco companies: they profess devotion to health and well-being, divert attention to physical activity, promote "better for you products" and create coalitions to reframe their message. ${ }^{58}$ In 2015, the New York Times revealed that Coca-Cola funded a research centre that advocated physical exercise to prevent obesity and downplayed the role of diet. ${ }^{59}$ In 2016, archival research showed that the sugar industry paid scientists to deliver research favourable to its interests. ${ }^{60}$ In general, industryfunded research has been found less likely to identify a link between soda consumption and weight gain. ${ }^{61}$

For these reasons, partnerships with industry have been critiqued, among which is the criticism that the industry's fiduciary duties to generate profits will outweigh public health. ${ }^{62}$ It has been suggested that, to be effective, partnerships should focus on environment-based interventions, not individual behaviours. ${ }^{63}$ Hawkes recommends that partnerships with the food

${ }^{53}$ IFOAM EU Group, 'Organic in Europe: Prospects and Developments 2016' (IFOAM EU Group 2016).

${ }^{54}$ Packaged Facts, 'Healthy-Ingredient Snacks in the U.S.' (2nd edn, Packaged Facts 2016).

${ }^{55}$ WHO, Framework Convention on Tobacco Control (adopted 21 May 2003, entered into force 27 February 2005) 2302 UNTS 166.

${ }^{56}$ Report of the Committee of Experts on Tobacco Industry Documents 'Tobacco Company Strategies to Undermine Tobacco Control Activities at the World Health Organisation' (WHO July 2000).

${ }^{57}$ Kelley Lee, World Health Organization (Global Institutions, Routledge 2009) 118-9.

${ }^{58}$ Marion Nestle, Soda Politics (Oxford University Press 2015) 107-113.

${ }^{59}$ Anahad O'Connor, 'Coca-Cola Funds Scientists Who Shift Blame for Obesity Away From Bad Diets' (New York Times, 2015) <http://well.blogs.nytimes.com/2015/08/09/coca-cola-funds-scientists-who-shift-blame-forobesity-away-from-bad-diets/?_r=0> accessed 15 May 2017.

${ }^{60}$ CE Kearns, LA Schmidt and SA Glantz, 'Sugar industry and coronary heart disease research: A historical analysis of internal industry documents' (2016) 176 JAMA Internal Medicine 1680.

${ }^{61}$ Maira Bes-Rastrollo and others, 'Financial Conflicts of Interest and Reporting Bias Regarding the Association between Sugar-Sweetened Beverages and Weight Gain: A Systematic Review of Systematic Reviews' (2014) 10 PLOS Medicine 1.

${ }^{62}$ Y Freedhoff, 'The food industry is neither friend, nor foe, nor partner' (2014) 15(1) Obes Rev 6.

${ }^{63}$ Vivica I Kraak and Mary Story, 'A Public Health Perspective on Healthy Lifestyles and Public-Private Partnerships for Global Childhood Obesity Prevention' (2010) 110(2) J Am Diet Assoc 192-200. 
industry are most likely to be effective where both par ties stand to gain, and where the partnership does not obstruct the broader strategy. ${ }^{64}$ She suggests that public-private partnerships should address a clear goal, map the parties' interests, and be monitored. ${ }^{65}$ Stuckler and Nestle, on the other hand, argue that there is an inherent conflict of interest as any partnership must create a profit for the food industry and unhealthy products are more profitable. Therefore, there is little incentive for companies to shift product category by choice. ${ }^{66}$ Garde and others concur that food companies have 'no incentive to voluntarily curb marketing for unhealthy food to children, except to foil efforts to enact potentially far-reaching legislation in this field' ${ }^{67}$

In light of weak WHO guidelines, the next section analyses whether food and beverage companies have direct responsibilities towards population health and diet under IHRL. My approach is that human rights can support and reinforce the realisation of public health goals, namely the prevention of childhood obesity. The connection between children's rights and obesity is increasingly recognised; in its recent report, ECHO specifically draws on children's rights, including the right to health. ${ }^{68}$ While WHO technical documents and recommendations are not binding, they could be used to interpret responsibilities under binding law. Further, unanimous political declarations from bodies made up by states, like the UN and WHA, are indicative of broad agreement and therefore persuasive. In order to pursue realisation of the right to health, human rights bodies should thereby draw on WHO technical documents to concretise broadly phrased human rights responsibilities.

\section{Companies under International Human Rights Law}

Since the 1970s, states, academics and civil society have discussed whether companies (particularly transnational entities) have or should have responsibilities to individuals under IHRL. International law is classically state-centric - states negotiate and ratify international treaties, and thereby consent to be bound by the provisions. Yet, while international law remains anchored to the nation state, globalisation has catapulted companies' transnational power, and undermined states' regulatory capacity. ${ }^{69}$ This governance gap allows companies to violate human rights and dignity, often without sanction. ${ }^{70}$

Despite these developments in global governance, states have been reluctant to impose binding human rights obligations on companies at the international level. Efforts to impose taxing standards, such as the proposed UN Norms on Transnational Corporations and Other

${ }^{64}$ Corinna Hawkes, 'Working Paper on Public-Private Partnerships for Health: High Level Group Working Paper on Public Private Partnerships for Health' (2008) 20-1.

${ }^{65}$ Ibid 21-2.

${ }^{66}$ David Stuckler and Marion Nestle, 'Big Food, Food Systems, and Global Health' (2012) 9(6) PLOS Medicine 2.

${ }^{67}$ Garde, Jeffrey, Rigby (n 48) 240.

${ }^{68}$ ECHO (n 11) 8. See also, Global Action Plan (n 43) 12. For a detailed analysis of the interplay between the WHO recommendations and children's rights, see Amandine Garde, Seamus Byrne, Nikhil Gokani and Ben Murphy, 'For a children's rights approach to obesity prevention: the key role of an effective implementation of the WHO Recommendations' (2017) 8(2) EJRR 327. See also, Amandine Garde and others, A Child Rights-Based Approach to Food Marketing: A Guide for Policy Makers (UNICEF, 2018).

${ }^{69}$ See, for example, Stephen J Kobrin, 'The Architecture of Globalization: State Sovereignty in a Networked Global Economy' in John H Dunning (ed) Governments, Globalization, and International Business (OUP 1999); David Antony Detomasi, 'The Multinational Corporation and Global Governance: Modelling Global Public Policy Networks' (2007) 71(3) J Bus Ethics 321.

${ }^{70}$ Mahmood Monshipouri, Claude E Welch and Evan T Kennedy, 'Multinational Corporations and the Ethics of Global Responsibility: Problems and Possibilities' (2003) 25 Hum Rts Q 965, 973. 
Business Enterprises ended in failure. ${ }^{71}$ Still, advocates have been inspired by the Universal Declaration of Human Rights (UDHR), which addresses 'every individual and every organ of society'. ${ }^{72}$ Under the UDHR, everyone has duties to the community and no group should engage in activities or acts that seek to destroy any rights and freedoms found within the Declaration. ${ }^{73}$ Although the UDHR is non-binding, it is often considered part of customary international law due to consistent state practice and opinio juris. ${ }^{74}$ Still, even if companies had binding obligations under the UDHR, there is no mechanism for monitoring or enforcing these at international level.

Further, as companies stand to benefit from engaging with human rights, their responsibilities must be clear and incisive. Businesses often adopt a human rights strategy due to public pressure, to reduce the threat of litigation, or the desire to boost their reputation. ${ }^{75}$ Therefore, vague guidance that allows companies to benefit reputationally by association with human rights, while doing very little to change corporate practices, should be avoided as only companies, not rights holders, will gain. ${ }^{76}$ Accordingly, I analyse the strategies below from the standpoint that companies must justify (and earn) the benefits of perceived human rights compliance with corporate transformation. Treating human rights as a mere means of corporate social responsibility runs contrary to the essence of human rights and the protection of human dignity.

\subsection{Existing business and human rights guidelines}

The central guidelines on business and human rights frame companies as holding responsibilities to respect human rights based on social expectations - not binding obligations enforced by law. ${ }^{77}$ Under the Global Compact, companies make two simple commitments specific to human rights: to support and respect all human rights recognised under the UDHR, and not to be complicit in rights abuses. ${ }^{78}$ The UNGP arguably go further; companies should respect all rights under the International Bill of Human Rights, ${ }^{79}$ by avoiding infringements and addressing any adverse impacts. The UNGP, although non-binding, is the most authoritative standard as it has been endorsed by the UN Human Rights Council, which is made up of states. The UNGP can further be interpreted in light of the Children's Principles that build on the UNGP from a child-centred outlook: companies should respect children's rights through preventing harm, and support children's rights through active engagement. ${ }^{80}$

\footnotetext{
${ }^{71}$ Norms on the Responsibilities of Transnational Corporations and Other Business Enterprises with Regard to Human Rights, adopted 13 Aug. 2003, Sub-Commission on the Promotion \& Protect. of Hum. Rts. Res. 2003/12, U.N. ESCOR, Comm'n on Hum. Rts, Sub- Commission on the Promotion \& Protect. of Hum. Rts., 55th Sess., U.N. Doc. E/CN.4/Sub.2/2003/12/Rev.2 (2003).

72 Universal Declaration of Human Rights (adopted 10 December 1948 UNGA Res 217 A(III) (UDHR).

${ }^{73}$ UDHR arts $29 \& 30$.

${ }^{74}$ United Nations, Statute of the International Court of Justice, 18 April 1946, 59 Stat. 1055, 3 Bevans 1179 art 38(1)(b).

75 Andrew Clapham, Human Rights Obligations of Non-State Actors (OUP 2006) 197.

${ }^{76}$ Surya Deva and David Bilchitz (eds), Human Rights Obligations of Business (CUP 2013) 229.

${ }^{77}$ Promotion and Protection of Human Rights, Interim Report of the Special Representative of the Secretary-General on the Issue of Human Rights and Transnational Corporations and Other Business Enterprises, U.N. ESCOR, Comm'n on Hum. Rts., 62d Sess, Provisional Agenda Item 17, U.N. Doc. ./CN.4/2006/97 (2006).

${ }^{78}$ United Nations Global Compact (2000), principles 1, 2.

${ }^{79}$ UNGP (n 5) 12.

${ }^{80}$ Children's Principles (n 5) Principle 3.
} 
What does it mean for a company to respect and support children's rights? Clearly, the responsibilities that companies voluntarily undertake are not onerous. Under the Global Compact, companies must make a leadership commitment to follow the principles, and produce an annual Communication on Progress (CoP). ${ }^{81}$ Following the UNGP, companies should avoid infringing human rights and address adverse impacts through 'prevention, mitigation and, where appropriate, remediation'. ${ }^{82}$ Yet, the UNGP do not define what constitutes an adverse impact, meaning that compliance relies on adequately defined human rights norms. The UNGP outline specific steps to meet these responsibilities, including a policy commitment, human rights duediligence and processes to enable remediation. ${ }^{83}$ The Children's Principles additionally call for child-sensitive remediation of adverse impacts. ${ }^{84}$

None of these standards amount to legally binding obligations. The agreements are not subject to monitoring or review, nor do they carry sanctions - besides reputational embarrassment or expulsion. The latter sanctions depend on third parties to identify and publicise non-compliance. Companies have wide latitude in determining whether, how, and when to address their adverse impact on human rights. Businesses may thereby use UN-associated principles to boost their profile, while not effectively addressing their negative impact on children's rights. Further, practice suggests that although many companies adopt human rights policies, the majority do not conform to the UNGP. ${ }^{85}$

Driven by the lack of specificity, Shift, a non-profit organisation, and Mazars, an international accountancy firm, developed a UNGP 'Reporting Framework' to guide companies in meeting the UNGP, based on two years of multi-stakeholder engagement. The Framework (Shift framework) introduces the concept of 'salient human rights issues': 'human rights that stand out because they are at risk of the most severe negative impact through the company's activities or business relationships' ${ }^{86}$ Following this approach, companies are not expected to address their impact on every right, but to identify the human rights that are most at risk by their actions in terms of scale (the severity of the impact), scope (the number of people that are affected) and remediability.

\subsection{A right to freedom from obesity?}

Although non-binding, existing standards on business and human rights call upon companies to respect and support children's rights. But what do these responsibilities entail in the context of childhood obesity prevention? While states must respect, protect and fulfil the rights enshrined in the treaties they ratify, companies should 'identify and assess' their actual or potential impacts on human rights, including through consultation with affected groups and stakeholders. ${ }^{87}$ Further, the UNGP do not articulate how companies should respect rights, and what conduct, if any, amounts to a violation of their responsibilities. This section analyses

\footnotetext{
${ }^{81}$ Global Compact, 'UN Global Compact Policy on Communicating Progress' (2013).

${ }^{82}$ UNGP (n 5) principle 11.

${ }^{83}$ Ibid principle 15.

${ }^{84}$ Children's Principles (n 5) 16.

${ }^{85}$ Susan Ariel Aaronson, 'Re-righting Business": John Ruggie and the Struggle to Develop International Human Rights Standards for Transnational Firms' (2013) 35(2) Hum R Q 333, 356.

${ }^{86}$ Shift/ Mazars, 'UN Guiding Principles Reporting Framework' (2015).

${ }^{87}$ UNGP (n 5) principle 18.
} 
companies' responsibilities in light of the treaties that enshrine relevant rights, guidelines on business and human rights, relevant general comments, and reports of Special Rapporteurs.

Human rights treaties recognise rights pertaining to healthy diet and obesity, yet not through the prism of companies' impact or duties. The CRC and ICESCR enshrine the rights to health and adequate food, which have a clear link to obesity, but only states can ratify the treaties. Under these treaties, states undertake obligations to combat disease, malnutrition, and epidemics, including through the provision of adequate food and clean water, and to develop preventative health-care. ${ }^{88}$ States parties must take steps, inter alia, to promote the healthy development of the child, and the prevention, treatment and control of epidemic, endemic, occupational and other diseases. ${ }^{89}$ Although the right to adequate food is classically linked to hunger in the 2014 Rome Declaration on Nutrition, member states of the Food and Agriculture Organization (FAO) and WHO reaffirm 'the right of everyone to have access to safe, sufficient and nutritious food' in the context of childhood overweight and obesity. ${ }^{90}$

Drawing on the Shift framework, food companies do not have to consider their impact on nutrition rights - they can focus upon selected human rights. Yet, the discussion in section 2.1 suggests that food and beverage companies have adverse impacts on the rights to health and adequate food, namely through producing, selling, and promoting ultra-processed foods, displacing healthy diets, targeting children through marketing unhealthy food, and lobbying against and obstructing evidence-based regulation. If we consider these impacts in terms of severity and scope, the rights to health and adequate food are arguably salient due to the depth of the obesity epidemic and the masses affected.

Further, although the Children's Principles also do not require companies to mitigate their adverse impact on the rights to adequate food and health specifically, unlike the UNGP, they highlight the impact of marketing of unhealthy food on children. Yet, marketing to children is not identified as contrary to children's rights per se. Instead, companies should ensure that their marketing practices do not have an adverse impact on children's rights. The accompanying Child Impact Assessment Guidelines encourage companies to make healthy food accessible in supermarkets, and avoid unhealthy food marketing in schools and 'child-friendly' sporting events. $^{91}$ The Children's Principles also posit that companies should comply with WHO recommendations on marketing. ${ }^{92}$

The recognition of the WHO recommendations on marketing reinforces the argument that public health recommendations can and should inform human rights. Still, like the WHO recommendations, the Principles are not binding. The Children's Principles are further less persuasive than the UNGP as they have not been endorsed by states. Further, terms like 'healthy' and 'child friendly' are undefined, allowing companies wide latitude. Additionally, the Children's Principles fail to draw attention to unhealthy food marketing as inherently adverse to children's rights, a conclusion that is merited in light of the evidence presented in section 2.1.

\footnotetext{
${ }^{88}$ CRC art 24.2(c).

${ }^{89}$ ICESCR art 12.

${ }^{90}$ ICESCR art 11; 'Rome Declaration on Nutrition' (Second International Conference on Nutrition FAO/ WHO, 1921 November 2014).

${ }^{91}$ Danish Institute for Human Rights, UNICEF, 'Children's Rights in Impact Assessments: A guide for integrating child rights into impact assessments and taking action for children’ (December 2013) 38.

92 Children's Principles (n 5) 26.
} 
Further, food companies' responsibilities could be informed by the general comments of UN committees tasked with monitoring the implementation of the CRC and ICESCR.$^{93}$ General comments, although not binding, are influential sources upon which civil society, businesses and states can draw. However, the CESCR primarily addresses states' obligations, with fleeting reference to companies' responsibility to respect Covenant rights. ${ }^{94}$ Conversely, the CRC Committee goes too far at times - claiming that all businesses have obligations of due diligence with respect to children's rights, obligations to carry out their operations in compliance with children's rights, ${ }^{95}$ and not to undermine states' abilities to meet their obligations. ${ }^{96}$ This interpretation of companies' duties is not principled, in that current international practice recognises companies as only having responsibilities - not obligations. ${ }^{97}$ Elsewhere, the CRC Committee has more accurately claimed that companies should limit unhealthy food marketing to children and comply with WHO standards (although it does not mention the WHO recommendations specifically). ${ }^{98}$

While the committees have offered limited guidance, the Special Rapporteur on the right to health and the Special Rapporteur on the right to food have made more direct recommendations to food companies. The former Special Rapporteur on the right to food advised companies to:

- Comply with WHO recommendations

- Avoid nutrition based interventions where diets are sustainable

- Prioritise local solutions with the objective of sustainable diets

- Move away from food high in salt, fat and sugar (HFSS) and towards healthier foods. ${ }^{99}$

In 2016 the current Special Rapporteur on the right to food called for internationally agreed guidelines on public/private partnership and independent monitoring of accountability. ${ }^{100}$ The Special Rapporteur on the right to health has reiterated several of the recommendations, calling on companies to:

- Adopt adequate nutritional labelling and comply with national guidelines,

- Avoid marketing, promoting and advertising HFSS foods (especially to children)

- Improve nutritional content of foods

\footnotetext{
${ }^{93}$ Ando N 'General Comments/ Recommendations' (Max Planck Encyclopaedia of Public International Law 2010) $<$ http://ilmc.univie.ac.at/uploads/media/general_comments_recommendations_empil.pdf> accessed 15 May 2017.

${ }^{94}$ CESCR, General comment No 24 (2017) on State obligations under the International Covenant on Economic, Social and Cultural Rights in the context of business activities (10 August 2017) E/C.12/GC/24 para 5.

${ }^{95}$ CRC Committee, 'General comment No 15: The right of the child to the enjoyment of the highest attainable standard of health' (17 April 2013) CRC/C/GC/15 para 75.

${ }^{96}$ CRC Committee, 'General comment No 16, State obligations regarding the impact of the business sector on children's rights' (17 April 2013) CRC/C/GC/16 para 8.

${ }^{97}$ See, John Tobin, The Right to Health in International Law (OUP 2012).

98 'General comment No 15' (n 95) para 81.

${ }^{99}$ Olivier De Schutter, 'Report submitted by the Special Rapporteur on the right to food' (26 December 2011) A/HRC/19/59 paras 51(a)-(d).

${ }^{100}$ Special Rapporteur on the right to food, 'Interim report of the Special Rapporteur on the right to food' (3 August 2016) A/71/282 para 99(e).
} 
- Increase transparency on nutritional information and avoid misleading claims

- Avoid undermining public health efforts. ${ }^{101}$

While these recommendations are non-binding, they recognise that food and beverage companies have a responsibility to mitigate their adverse impact on children's (and adults') rights to health and adequate food. They provide detail on what it means to respect and support rights in the context of obesity. Yet, as discussed in section 4, there is an overlap between some of these responsibilities and states' obligations. The next section analyses whether selected food and beverage companies have operationalised the non-binding responsibilities discussed in this section in their human rights policies to date.

\subsection{Selected companies' human rights policies}

In light of the guidance from human rights bodies discussed above, I now analyse a selection of human rights policies to establish whether major food and beverage companies assess their adverse impacts on the right to adequate food and the right to health in the context of obesity. In analysing companies' responsibilities, I am guided by Shift's framework which recommends that companies determine which rights are "salient". However, salience still leaves companies wide discretion. Therefore, in assessing which rights are "salient", I argue that companies should be guided by what Bilchitz terms the "functional objection". According to Bilchitz, the Ruggie Principles suggest that companies' responsibilities should 'track the nature and function that the entity has in our society'. ${ }^{102}$ Thus, companies' responsibilities should be connected to their role and aims as this is where companies can have the greatest impact (whether positive or negative). Therefore, 'an understanding of the function of particular entities is... crucial in delineating the nature and ambit of their obligations'. ${ }^{103}$

Following this approach, companies' human rights policies should analyse the companies' impact on the rights closely linked to their aims and functions. Companies should not be free to determine "salient issues". As a company is a profit-making entity, it is logical that it will avoid exposing itself to losses and decline to voluntarily limit profitable activities. Applying this paradigm to food companies (as profit-making entities with the main objective of selling food), and given the link between unhealthy diet and obesity and other noncommunicable diseases, companies should examine the impact of their products on individuals' and communities' rights to health and adequate food in order to effectively respect human rights. This requires companies to engage with the adverse impacts of their products and the potential rights violations that can flow from their activities - not to merely pick the rights that they consider easiest to address.

Yet, the food and beverage companies reviewed do not engage with the effect of their products on the right to health or the right to adequate food. Despite the close connection between the rights and the societal role of the companies, food and beverage companies do not identify the direct link between producing and selling food, and individuals' rights to adequate food and health, as a human rights responsibility. Instead, the companies focus on employmentcentred rights and duties, such as prohibition of child labour, land rights and working

${ }^{101}$ UN Human Rights Council, 'Report of the Special Rapporteur on the Right of Everyone to the Enjoyment of the Highest Attainable Standard of Physical and Mental Health' (1 April 2014) A/HRC/26/31 paras 66(a)-(e).

${ }^{102}$ David Bilchitz, 'Do Corporations Have Positive Fundamental Rights Obligations?' (2010) Theoria 1, 5.

${ }^{103}$ Ibid. 
conditions. ${ }^{104}$ Food companies' approach to human rights suggest that by protecting their workers, they have done their part to respect human rights; the effects of their products are for the consumer to weigh and decide whether to purchase.

This minimalist approach echoes the informed-consumer paradigm, whereby consumers, not the producer, are primarily responsible for their health and food choices. ${ }^{105}$ Following this approach, individuals are conceived as rational choice maximisers who are able to understand and evaluate information, and act on the information in the interests of their health when making purchases. In the context of obesity, such an approach is underscored by individual responsibility and the politics of blame. Yet, obesity is more complex than simply individual behaviour. ${ }^{106}$ Further, behavioural economics questions the extent to which individuals make rational choices in their long-term interests. ${ }^{107}$

However, while "big food" companies do not assess obesity as a human rights responsibility, they recognise that obesity risks their profitability. Companies thereby analyse obesity as an economic, but not a human rights, impact. For instance, Coca-Cola sees obesity as a threat that may lead consumers to change purchasing habits, and cause legislatures to regulate labelling and marketing. ${ }^{108}$ Similarly, PepsiCo concedes that a public impression that it is not meeting its targets in reducing unhealthy advertising and reformulating products could have an adverse effect on its business. ${ }^{109}$ The company further recognises that it has a responsibility to address obesity and thereby supports active lifestyle initiatives. ${ }^{110}$ General Mills draws specific attention to overweight and obesity, and claims to reformulate its products to support consumers. ${ }^{111}$

Accordingly, food and beverage companies do not avoid engagement with the nutritional aspects of food or health, but approach these factors separately from human rights. Companies are aware of their relationship to individuals' access to adequate food and their enjoyment of the right to health, although they do not phrase it as such. Instead, obesity has been framed as a public relations exercise and thereby a marketing opportunity. For instance, General Mills recognises 'healthy and affordable food' in the context of food security, health and nutrition wellness, but not human rights. It reports that it has reduced the amount of salt and sugar in its products and supports community efforts to live a healthful life. ${ }^{112}$ Similarly, although Coca-

${ }^{104}$ General Mills, 'Policy on Human Rights' (2016); Coca-Cola, 'Human Rights Policy' (2014); McDonald's, 'The Good Business Report' (McDonald's Sustainability Update, 2015); PepsiCo, 'Sustainability Report 2014 Performance with Purpose' (2015); Coca-Cola, '2014/2015 Sustainability Report' (2015); Mars, 'Human Rights Policy' (2016).

105 Paul Cairney and Donley Studlar, 'Obesity Prevention Policy: From Harm Regulation Towards a NeoProhibitionist Regime?’ (2015 University of Strathclyde).

${ }^{106}$ CA Roberto and others, 'Patchy progress on obesity prevention: emerging examples, entrenched barriers, and new thinking' (2015) 385 Lancet 2400.

${ }^{107}$ Richard H Thaler and Cass R Sunstein, Nudge: Improving Decisions About Health, Wealth and Happiness (Penguin Books 2009) 6; CA Roberto and I Kawachi, 'Use of Psychology and Behavioral Economics to Promote Healthy Eating' (2014) 47(6) Am J Prev Med 832.

108 The Coca-Cola Company, 'United States Securities and Exchange Commission Form 10-K' (2015).

${ }_{109}$ Pepsico, '2015 Annual Report' (2016) 19; Mondelez International, 'Form 10-K Annual Report' (2016) 18.

${ }^{110}$ Pepsico, 'Performance with Purpose 2025 Agenda: PepsiCo Sustainability Report 2015' (2016) 3.

111 General Mills, 'Global Responsibility 2015' (2016) 18. McDonald's are more discrete but mention that customer's perceptions of nutritional content of the food poses a risk, McDonald's, 'Annual Report' (2015) 4.

112 General Mills, 'Global Responsibility 2016' (2016) 93-102; Mars recognise obesity as a challenge, Mars, 'Principles in Action Summary 2013' (2014) 9. 
Cola does not consider the effect of its products on its consumers as right to health or food issues, it details product reformulation in its separate 'Sustainability' Report. ${ }^{113}$ 'Well-being', which is separated from human rights, includes taking measures to offer low calorie options, nutrition information, supporting physical activity and avoiding marketing directed at children under 12 years. ${ }^{114}$ PepsiCo also reports on product reformulation and portion size reduction in its Sustainability Report. ${ }^{115}$ Like its competitors, Mondelez International reports on 'well-being' separately from human rights. It details efforts to introduce new (self-defined) 'better for you' products and claims that $25 \%$ of its sales come from 'better for you' products. ${ }^{116}$ Mc Donald's invests in, and supports, 'making physical activity fun' by promoting exercise through sponsorship of events at local and global level. ${ }^{117}$ Mars recognises obesity as a concern and pursues information provision, food reformulation and community outreach, such as cooking lessons. ${ }^{118}$

Nestlé recognises broader human rights concerns than the other companies, having commissioned the Danish Institute for Human Rights to conduct an analysis of its human rights impact in eight distinct areas, including marketing practices. ${ }^{119}$ Product safety (although not nutrition) is recognised as a human rights concern, suggesting that there could be scope for expanding this interpretation to include nutrition standards. ${ }^{120}$ The company further identifies employee health and well-being as a human rights responsibility, which could be expanded to consider consumers' health. ${ }^{121}$ Finally, Nestlé acknowledges water as a basic human right. ${ }^{122}$ Nestlé's efforts to demonstrate commitment to human rights is a response to the criticism it received for aggressively marketing infant formula and interfering with the right to water through buying water permits. ${ }^{123}$

Table 1: Selected Human Rights Policies

\begin{tabular}{|c|c|c|}
\hline $\begin{array}{l}\text { Company } \\
\text { reviewed }\end{array}$ & Consideration of human rights & $\begin{array}{l}\text { Corporate Social responsibilities (CSR) related } \\
\text { to obesity }\end{array}$ \\
\hline Coca-Cola & $\begin{array}{l}\text { Non-existent, but obesity threatens } \\
\text { profits. } \\
\text { Child labour; work hours, wages } \\
\text { and benefits; forced labour and } \\
\text { human trafficking; workplace } \\
\text { security; safe and healthy } \\
\text { workplace, diversity; freedom of }\end{array}$ & $\begin{array}{l}\text { Sustainability: } \\
\text { - } \quad \text { Product reformulation } \\
\text { Well-being: } \\
\text { - } \quad \text { Offer low calorie options } \\
\text { - } \quad \text { Provide nutrition } \\
\text { - } \quad \text { information } \\
\text { - } \quad \text { Support physical activity }\end{array}$ \\
\hline
\end{tabular}

\footnotetext{
${ }^{113}$ Coca-Cola, 2014/2015 'Sustainability Report'.

114 Ibid 6.

115 PepsiCo, 'Sustainability Report 2014' 6.

116 Mondelez International, 'The Call for Wellbeing: Progress Report' (2016) 33.

${ }^{117}$ Mc Donald's, 'The Good Business Report' 35.

118 Mars, 'Principles in Action Summary 2013' 20.

${ }^{119}$ Nestle, 'Nestlé in society: creating Shared Value and meeting our commitments 2015' (2016) 225.

${ }^{120}$ Ibid 250-3.

${ }^{121}$ Ibid 269.

122 Ibid 138

${ }^{123}$ Nestle, 'Does Nestlé Chairman Peter Brabeck-Letmathe believe that water is a human right?' $<$ http://www.nestle.com/ask-nestle/human-rights/answers/nestle-chairman-peter-brabeck-letmathe-believeswater-is-a-human-right> accessed 15 May 2017.
} 


\begin{tabular}{|c|c|c|}
\hline & $\begin{array}{l}\text { association and collective } \\
\text { bargaining; community engagement }\end{array}$ & $\begin{array}{l}\text { - Avoid marketing directed at children under } \\
12 \text { years }\end{array}$ \\
\hline PepsiCo & $\begin{array}{l}\text { Freedom of association, right to } \\
\text { water, land rights, vulnerable } \\
\text { workers, working hours and wages, } \\
\text { workplace safety }\end{array}$ & $\begin{array}{l}\text { Sustainability: } \\
\text { - } \quad \text { Product reformulation } \\
\text { - } \quad \text { Support active lifestyle } \\
\text { - } \quad \text { Reduce portion sizes }\end{array}$ \\
\hline General Mills & $\begin{array}{l}\text { Forced labor, child labor, and } \\
\text { discrimination; safe and healthy } \\
\text { working conditions; diversity; } \\
\text { wage, work hours, overtime and } \\
\text { benefits laws; freedom of } \\
\text { association and collective } \\
\text { bargaining; land rights; } \\
\text { implementation of FPIC }\end{array}$ & $\begin{array}{l}\text { Responsibility: } \\
\text { - } \quad \text { Reformulation } \\
\text { - } \quad \text { Healthy \& affordable food } \\
\text { - } \quad \text { Support communities to live 'healthy life' }\end{array}$ \\
\hline Mondelez Int'I & $\begin{array}{l}\text { Workers, direct suppliers \& broader } \\
\text { community should be treated with } \\
\text { dignity }\end{array}$ & $\begin{array}{l}\text { Well-being: } \\
\text { - Product reformulation }\end{array}$ \\
\hline Mc Donald's & $\begin{array}{l}\text { Suppliers should respect rights, } \\
\text { Freedom of Association, } \\
\text { employment status, employment } \\
\text { practices, anti-discrimination \& fair } \\
\text { treatment, working hours \& rest } \\
\text { days, underage labor, wages \& } \\
\text { benefits }\end{array}$ & $\begin{array}{l}\text { Good-Business: } \\
\text { - Promoting physical activity incl } \\
\text { sponsorship }\end{array}$ \\
\hline Mars & $\begin{array}{l}\text { Health (including environmental } \\
\text { health, workplace health \& safety) } \\
\text { Workplace diversity / non- } \\
\text { discrimination } \\
\text { Forced labour and human } \\
\text { trafficking (including in supply } \\
\text { chains) } \\
\text { Sexual harassment } \\
\text { Freedom of association and trade } \\
\text { union rights } \\
\text { Women } \\
\text { Children (including child labour) } \\
\text { Indigenous peoples } \\
\text { Migrant workers }\end{array}$ & $\begin{array}{l}\text { Principles in Action: } \\
\text { - } \quad \text { information provision } \\
\text { - } \quad \text { food reformulation } \\
\text { - community outreach }\end{array}$ \\
\hline Nestlé & $\begin{array}{l}\text { Freedom of association } \\
\text { and collective bargaining; working } \\
\text { time; workers' accommodation; } \\
\text { safety \& health; living wage; child } \\
\text { labour; land acquisition; access to } \\
\text { water \& sanitation; access to } \\
\text { grievance mechanisms; data } \\
\text { protection \& privacy }\end{array}$ & $\begin{array}{l}\text { Nutrition, health \& wellness: } \\
\text { - } \quad \text { Reformulation } \\
\text { - } \quad \text { Nutrition education } \\
\text { - } \quad \text { Clear information } \\
\text { - } \quad \text { Marketing }\end{array}$ \\
\hline
\end{tabular}




\subsubsection{Voluntary marketing commitments}

Despite their responsibilities under the WHO recommendations, states often fail to perform a leadership role in regulating food marketing. Instead, companies self-regulate through collective and individual pledges. In light of globalisation, collective pledges, if effective, can contribute to protecting children's rights across borders. Yet, the pledges are currently too weak to uphold children's rights. Instead, food and beverage companies present a united front through mobilising as a collective, adding to their lobbying power and, consequently, to their ability to ward off regulation.

For instance, major food and beverage companies created and agreed to a set of selfregulatory principles under the prism of the International Food and Beverage Alliance (IFBA). ${ }^{124}$ Companies commit to advertise only products that meet nutritional criteria to children under 12 (meaning programmes with an audience profile of which over $35 \%$ are children). Accenture independently monitors these commitments on an annual basis. Yet, the IFBA has limitations: it only protects children under age 12, the audience threshold for advertising to be directed at children is high, and the companies that produce the products set the nutritional criteria. Furthermore, compliance and effective monitoring is weak. The 2015 compliance report claims $97 \%$ television compliance - meaning over 14,000 examples of non-compliance were identified. In contrast, British regulations on food marketing enshrine a more protective model that requires pre-clearance, meaning that children are exposed to less harmful advertising in the first instance, and are not solely reliant on complaints. ${ }^{125}$ Returning to the IFBA, while $100 \%$ print compliance was reported, this was only in print directly targeting children under 12 - not print that children actually read, such as magazines designed for teenagers. Also, the system of monitoring internet communications only measures a sample of sites directly targeting children, meaning that a significant amount of advertising that children are exposed to is most likely not captured. ${ }^{126}$ If monitoring is difficult due to challenges in determining how targeting is defined, it must be similarly problematic for companies to determine where and when advertising may be placed.

Additionally, the companies reviewed in this article make individual marketing commitments on top of collective pledges, suggesting that some companies recognise the insufficiency of collective pledges. Individual voluntary commitments that go beyond the collective pledges include: prohibiting all direct advertising to children under 12 and targeting parents instead; ${ }^{127}$ not using celebrities or licensed characters in marketing aimed at children; ${ }^{128}$ only using licensed characters and endorsements where products meet set nutritional criteria; ${ }^{129}$ more narrowly defining when children are the targets of adverting (i.e. where $25 \%$ of the audience are under $12,{ }^{130}$ in contrast to $35 \%$ children as defined by the IFBA). ${ }^{131}$ However,

\footnotetext{
${ }^{124}$ The member companies are The Coca-Cola Company, Ferrero, General Mills, Grupo Bimbo, Kellogg's, Mars, McDonald's, Mondelēz International, Nestlé, PepsiCo and Unilever. ( $<$ www.ifballiance.org/about/members/>). There a number of other regional pledges, such as the EU Pledge http://www.eu-pledge.eu/

${ }^{125}$ British Heart Foundation and CFC, 'Protecting Children from Unhealthy Food Marketing' (Sustain 2008) 24.

${ }^{126}$ Ibid 4.

${ }^{127}$ Mondelez International, ‘The Call for Wellbeing: Progress Report' 40; Coca-Cola, 'The Coca-Cola Company's Responsible Marketing Policy’ (September 2015).

${ }^{128}$ Mars, 'Global Marketing Code for Food, Chocolate, Confections and Gum' 3.

${ }^{129}$ Ibid 2.

${ }^{130}$ Ibid 8.

${ }^{131}$ PepsiCo, 'PepsiCo Policy on Responsible Advertising to Children.
} 
these commitments are undermined where companies apply weak nutritional criteria. ${ }^{132}$ On the one hand, the fact that some companies voluntarily go further than others may prompt a race to the top, where companies seek to boost their reputation by voluntarily employing progressively stricter standards. On the other hand, the patchwork of varying commitments undermines the universality of rights; children's rights protection is dictated and defined by companies subject to their will, not regulators motivated by children's rights.

\subsection{The unfulfilled promise of rights}

The decision of the food companies reviewed to focus on employment rights, not the rights that are central to their function in society exposes an effectiveness gap in the current approach to business and human rights. The analysis suggests that food companies are slow to analyse their impact on consumers' health and access to adequate food through a human rights paradigm. Instead, the companies reviewed engage with nutrition as a form of corporate sustainability.

Although several companies voluntarily restrict their marketing, including through global responsible marketing pledges, they design their own criteria, which are not sufficiently robust. ${ }^{133}$ Due to the inherent conflicts, this leads to varied, sub-optimal standards of protection. For example, the Access to Nutrition Index (a non-profit organisation) reports that Mars' nutrient profiling only applies to its non-confectionary products, which make up a mere $5 \%$ of its product portfolio. ${ }^{134}$ Further, where pledges narrowly define "advertising to children", children continue to view high levels of advertising. Further, as companies' voluntary commitments are mostly self-monitored, it is unclear whether they truly honour the spirit of their promises. Also, companies do not ensure accessible child-centred complaints mechanisms as recommended under the Children's Principles.

Using the language of the WHO Recommendations, limitations must effectively reduce children's exposure to, and the power of, food marketing. Otherwise, as discussed above, companies can highlight their self-defined 'responsible' behaviour and benefit reputationally, without effectively limiting their promotional activities. Bryden et al. conclude that the evidence on voluntary agreements is too limited to claim that they are as effective as legislation. ${ }^{135}$

Also, companies claim not to market to children, but often indirectly and directly promote their brand through sponsorship. As clear from table 1, some companies even portray this form of marketing as a beneficent means of combating obesity. Food brands further sponsor major international sporting events that attract billions of viewers. For instance, McDonald's is among the brands that acts as official sponsor of the FIFA World Cup, while Coca-Cola sponsors both the Olympics and FIFA competitions. At local level, food industry sponsorship of sports for

${ }^{132}$ General Mills, 'Marketing and advertising' (2016).

${ }^{133}$ The limitations of self-regulation are well documented. See for example, C Hawkes and J Harris, 'An analysis of the content of food industry pledges on marketing to children' (2011) 14(8) Public Health Nutrition 1403; J Jensen and K Ronit, 'The EU pledge for responsible marketing of food and beverages to children: implementation in food companies' (2015) 69(8) Eur J Clin Nutr 896; Oliver Huizinga and Michaela Kruse, 'Food Industry Self-Regulation Scheme "EU Pledge" Cannot Prevent the Marketing of Unhealthy Foods to Children' (2016) Obesity Medicine 1.

134 'Mars' (Access to Nutrition Index 2016) <https://www.accesstonutrition.org/index/2016/company/mars > accessed 15 May 2017.

${ }^{135}$ A Bryden and others, 'Voluntary agreements between government and business - a scoping review of the literature with specific reference to the Public Health Responsibility Deal' (2013) 110 Health Policy 186, 191. 
young people is prevalent and comes more commonly from companies promoting unhealthy food than those promoting healthful products. ${ }^{136}$ This is not mere philanthropy; children recall sports' shirts sponsors, ${ }^{137}$ and form a positive impression of the company. ${ }^{138}$ Indeed, the strategy is profitable: during the London 2012 Olympics, sales of sugary drinks increased by $10 \%$ in value and $8 \%$ in volume, compared with the same period the year before. ${ }^{139}$ It is even more duplicitous that the same companies lobby behind closed doors using science, civil society, media and policy. ${ }^{140}$ Leading soda companies extensively sponsor public health organisations, while lobbying against regulation. ${ }^{141}$

This is contrary to a human rights approach. If companies are truly serious about investing in children's health, they should do so without using their logos, and cease selling or promoting unhealthy products at events frequented by children. The Special Rapporteur on the Right to Health recommends that states ban advertising, promotion and sponsorship of all events which could be attended by children by manufacturers of alcohol, tobacco and unhealthy foods. ${ }^{142}$ argued in the case of pharmaceutical companies, ${ }^{143}$ food companies should cease lobbying that undermines the right to health. Companies cannot write off their negative impact on nutrition rights and contribution to obesity by investing in exercise and sports. This is supported by the UNGP that prohibit instrumentalising rights. ${ }^{144}$ By claiming to support physical activity, companies present a commercial opportunity as corporate social responsibility. This reinforces the inaccurate claim that exercise alone will reverse obesity trends.

It is significant that companies see health and nutrition through the lens of corporate social responsibility, not a responsibility to respect the human rights that are central to their profits. This allows corporate actors to address their adverse impact through beneficence, not fulfilment of responsibilities to their consumers defined in consultation with stakeholders. It is further in contrast to the approaches of human rights bodies, analysed in section 3.2, that underscore product reformulation, information and marketing bans as companies' human rights responsibilities. The approach of food companies signals reluctance to acknowledge the potential conflicts between their products and human rights. Practically speaking, recognising product reformulation as a human rights impact could highlight states' legal duties to regulate, which

${ }^{136}$ A Maher and others, 'Patterns of sports sponsorship by gambling, alcohol and food companies: an Internet survey' (2006) 6 BMC Public Health 95; R. Macniven, B. Kelly and L. King, 'Unhealthy product sponsorship of Australian national and state sports organisations' (2015) 26 Health Promot J Austr 52.

${ }^{137}$ A. Bestman and others, 'Children's implicit recall of junk food, alcohol and gambling sponsorship in Australian sport' (2015) 15 BMC Public Health 1022.

${ }^{138}$ B Kelly and others, '"Food company sponsors are kind, generous and cool": (mis)conceptions of junior sports players' (2011) 8 Int J Behav Nutr Phys Act 95.

${ }^{139}$ Honor Whiteman, 'Should 'junk food' companies be sponsoring major sporting events?' Medical News Today (2014) <http://www.medicalnewstoday.com/articles/278521.php > accessed 15 May 2017.

${ }^{140}$ David Miller and Claire Harkins, 'Corporate strategy, corporate capture: Food and alcohol industry lobbying and public health' (2010) 30(4) Critical Social Policy 564.

${ }^{141}$ Daniel G Aaron and Michael B Siegel, 'Sponsorship of National Health Organizations by Two Major Soda Companies' (2017) 52 American Journal of Preventive Medicine 20.

${ }^{142}$ Report of the Special Rapporteur on the right of everyone to the enjoyment of the highest attainable standard of physical and mental health A/HRC/32/33, para 101(b).

${ }^{143}$ Report of the Special Rapporteur on the right of everyone to the enjoyment of the highest attainable standard of physical and mental health A/63/263, Guideline 26.

${ }^{144}$ UNGP (n 5) principle 11 states that "while business enterprises may undertake other commitments or activities to support and promote human rights, ... this does not offset a failure to respect human rights throughout their operations". 
companies are likely to wish to avoid. Further, drawing on 'remediability' within the Shift framework, these impacts may not be easy for companies that predominately sell unhealthy products to address without affecting profits.

\section{$4 \quad$ Ways forward}

This review has highlighted that, at present, food companies hold only non-binding responsibilities to respect rights, which lack effective oversight or sanctions where adverse impacts occur. Companies largely choose whether or not, and the extent to which, they engage with human rights, and they have too much latitude in determining which adverse impacts on human rights to address. This allows food companies to contribute to the obesity crisis, while simultaneously claiming to respect human rights. The present trajectory may worsen. As demand for healthy food grows in developed markets, food companies move their strategies to low and middle income economies. Even if states regulate more effectively in line with their obligation to protect, without universal protections, a fragmented legal landscape with different levels of protection from state to state will endure. Although global pledges, like the IFBA, could ensure global standards, they are currently too weak to provide for effective enjoyment of rights. Despite this bleak picture, several avenues to entrench greater commitment to human rights exist.

Firstly, the United Nations is at an early stage of drafting an international treaty on business and human rights. This follows the 2014 Human Rights Council decision to establish an open-ended intergovernmental working group to explore a binding instrument on business and human rights. ${ }^{145}$ In October 2017, the intergovernmental working group presented elements for a draft legally binding instrument for substantive negotiation. ${ }^{146}$ Like the UNGP, the draft elements propose that states retain the primary obligations to respect, protect and fulfil rights, while businesses have a duty to respect all human rights. ${ }^{147}$ The function of the binding treaty, in contrast to the UNGP, is to establish legal liability for companies, and mechanisms for justice and remedy for individuals. ${ }^{148}$ Although the negotiations are fledgling, the prospect of a binding treaty on business and human rights, which once seemed fleeting, is closer than ever.

For the purposes of our discussion above, the treaty could have interesting implications. In its current form, the draft elements seek to 'reaffirm the primacy of human rights law over trade and investment agreements'. ${ }^{149}$ This could strengthen countries' regulatory basis and defence against litigation when, inter alia, adopting regulations to prevent obesity. Further, the draft elements recognise the universality of rights, which includes the rights to adequate food and health. The draft also draws attention to states' obligations to ensure that public procurement respects human rights, ${ }^{150}$ a legal avenue that could be used to argue for adequate food in public institutions. Further, states have a reinforced role in monitoring and ensuring the adequacy of companies' human rights policies, thus potentially giving more leverage to guide companies in compliance with the rights most linked to their function. Vitally, businesses' obligations are not

\footnotetext{
${ }^{145}$ Human Rights Council, 'Elaboration of an international legally binding instrument on transnational corporations and other business enterprises with respect to human rights' (14 July 2014) A/HRC/RES/26/9.

146 'Elements For The Draft Legally Binding Instrument On Transnational Corporations And Other Business Enterprises With Respect To Human Rights' established by HRC Res. A/HRC/RES/26/9'.

${ }^{147}$ Ibid principles 1.2 .

148 Ibid Purpose 1.3.

149 Ibid Objectives 1.4.

${ }^{150}$ Ibid Obligations of states 3.1.
} 
only negative; they must also prevent human rights impacts. ${ }^{151}$ Although loosely phrased, companies' obligation to 'use their influence' to promote and ensure respect for rights could be used to argue against lobbying contrary to the rights to health and food. The draft moots new mechanisms for pursuing compliance, including the establishment of an international court or committee. ${ }^{152}$

While a new treaty could strengthen protection, it also raises several questions. Can the international community agree on a sufficiently robust instrument? A treaty will achieve little if it fails to enshrine strong standards. ${ }^{153}$ Already, the international business community is united against binding human rights obligations. ${ }^{154}$ Further, even if a treaty were adopted, would enough states ratify? The failure of most states to ratify the Migrant Rights Convention demonstrates that agreeing on treaty text is insufficient and not automatically followed by widespread ratification, particularly by the states that fear they will incur the greatest burden. ${ }^{155}$ It is unlikely that the treaty could bind businesses without state ratification and, in some cases, implementation into national law. When a dualist state ratifies a treaty, it also needs to incorporate the treaty into national law to ensure that its provisions take effect. Indeed, it must be asked whether treaties are more effective than soft law commitments, such as the WHO recommendations. Both require political will and resources.

Secondly, in the meantime and beyond, states could adopt a more active role in underscoring food companies' responsibilities to respect children's rights to adequate food and health, while simultaneously taking their obligation to protect more seriously. States should urge companies to identify human rights that are truly salient to their business and ensure that any corporate sponsorship upholds children's best interests. In highlighting companies' responsibilities to the rights to adequate food and health, states should call on companies to comply with WHO recommendations that concretise responsibilities in the context of obesity. At the same time, states and businesses' responsibilities must not be conflated. States should adopt national action plans on implementing the UNGP and identify areas where legislation is necessary to ensure compliance, such as where conflict of interests between companies and the public render self-regulation inappropriate. Further, states should pursue transparency in their interactions with the food industry and avoid conflicts. Yet, countries that do not fully recognise socioeconomic rights - such as the US, which has neither ratified the ICESCR nor CRC - are unlikely to take an active role in requiring companies to respect these rights, and instead focus on compliance with civil and political rights.

Thirdly, as companies' responsibilities in relation to obesity are ill-defined, civil society and academics could develop business and human rights indicators to guide companies and press

\footnotetext{
${ }^{151}$ Ibid Obligations of TCs 3.2.

152 Ibid Preventive Measures 4.

${ }^{153}$ Geoffrey Cannon, 'Why the Bush administration and the global sugar industry are determined to demolish the 2004 WHO global strategy on diet, physical activity and health' (2004) 7 Public Health Nutrition 369.

${ }^{154}$ International Chamber of Commerce, UN treaty on business and human rights: business response to elements for a draft legally binding instrument (20 October 2017) https://iccwbo.org/publication/un-treaty-business-humanrights-business-response-elements-draft-legally-binding-instrument/ accessed 16 November 2017.

${ }^{155}$ Currently only 48 states have ratified the CMW, see, 'Ratification Status for CMW - International Convention on the Protection of the Rights of All Migrant Workers and Members of Their Families', available here: http://tbinternet.ohchr.org/_layouts/TreatyBodyExternal/Treaty.aspx?Treaty=CMW\&Lang=en.
} 
for implementation. ${ }^{156}$ So, what would business and human rights' indicators look like in relation to childhood obesity? Some emerging practices on the right to water may provide guidance. ${ }^{157}$ For instance, both Nestlé and PepsiCo consider their impact on communities' rights to physical acceptability and affordability of water. ${ }^{158}$ In academic discourse, it has been asserted that companies must not over-consume or deplete community water. They should ensure that individuals have access to 'safe, sufficient, acceptable, accessible and affordable water'. ${ }^{159}$ Achieving this requires greater consideration of companies' broader impact on communities. For example, following complaints, the dairy company Arla conducted human rights impact assessments in Nigeria and Senegal to establish the extent to which supplying powdered milk in those markets would affect local farmers. The report centred on the company's impact on farmers' rights to an adequate standard of living, not the public's right to adequate food. ${ }^{160}$ Arguably, the same due diligence could be applied to food companies' impact on sustainable diets.

\section{Conclusion}

As inalienable, universal norms, human rights could be a force to demand accountability for global food and beverage companies' negative impacts on children's rights to health and adequate food. Yet, human rights practice in the field of obesity prevention is underdeveloped. Because of the inherent flexibility of the UNGP, food and beverage companies currently promote consumer 'choice' as CSR, while ignoring children's rights to adequate food and health. This article progresses the discourse on food companies and human rights, but further research is needed.

The article argued that food and beverage companies should analyse their adverse impact on the rights to adequate food and health, in the context of childhood obesity. Drawing on the Shift framework and Bilchitz's research, it is reasonable to demand that food companies to consider these rights at the core of their functions, and in light of the scale and scope of the impact. The analysis has yielded a first proposal for how food and beverage companies can analyse their impact on the rights closest to their business. ${ }^{161}$ To respect these rights, companies should cease undermining public health, such as through lobbying regulators to weaken evidence-based laws and attacking science. Further, human rights recommendations emphasise that food companies should avoid displacing sustainable healthy diets, and reformulate unhealthy products. Emerging practice on the right to water suggests that food companies should, in

${ }^{156}$ Damiano de Felice, 'Business and Human Rights Indicators to Measure Corporate Responsibility to Respect: Challenges and Opportunities' (2015) 37 Hum Rts Q 511531.

${ }^{157}$ See further: General Assembly, Resolution adopted 28 July 2010 'The human right to water and sanitation' (3 August 2010) A/RES/64/292 3; CESCR, 'General Comment No. 15: The Right to Water (Arts. 11 and 12 of the Covenant)' (20 January 2003) E/C.12/2002/11.

158 Pepsico, 'PepsiCo Guidelines in Support of the Human Right to Water'.

159 Aaronson (n 85) 358.

160 Arla, 'Human Rights Assessment in Nigeria Report November 2015' (2016).

${ }^{161}$ Since the acceptance of this article for publication, Handsley and Reeve have also scoped food companies' human rights responsibilities. They suggest a number of reforms to the UNGP: disclosure of the company's human rights methodology and results, more robust external engagement and independent monitoring, and 'naming and shaming' of companies that do not comply. E Handsley and B Reeve, 'Holding Food Companies Responsible for Unhealthy Food Marketing to Children: Can International Human Rights Instruments Provide a New Approach?' (2018) 41(2) UNSW Law Journal 1, 37. 
consultation with stakeholders, assess communities' rights and nutritional need before entering new markets. The entry of processed food into developing countries can collapse local food sellers. ${ }^{162}$ Nutritional needs must be defined in line with evidence-based guidelines, not companies' own, compromised nutrition models.

Companies should further be guided by recommendations from organisations with complementary aims to human rights bodies, such as WHO. Drawing on WHO recommendations, to respect children's rights, companies should ensure that pledges aim to reduce the impact of unhealthy marketing, and reduce exposure and power of such marketing. Companies should avoid marketing unhealthy food, instead promoting nutritionally adequate foods. Commitments should be independently monitored, and child-friendly complaints mechanisms with remedies made available. Finally, companies should honour their commitments without promoting their brands. Instead of events like the Olympics being dominated by fries and sodas, healthy imagery without branding could have a far more positive impact on health.

However, states remain the main duty bearers and should, including through WHO, shape an environment that compels companies to respect rights. As food and beverage companies have a conflict of interest, government regulators, in consultation from public health experts, should set legal parameters, such as, which food is healthy or unhealthy, and what information must be disclosed on labelling. Given their obligations under the CRC and ICESCR, states must play a vital role in scoping companies' responsibilities and defining key terms like 'healthy' and 'children', which food and beverage companies are unsuitable to do. Where pledges do not meet their aims, regulators must act, not merely threaten.

${ }^{162}$ Stuckler and others (n 26) 2. 